\title{
IDEOLOGICAL INVOLUTION OF THE ISLAMISTS
}

FawaizuโUmam

Institut Agama Islam Negeri Jember, Indonesia

E-mail: fawaizu@yahoo.com

\section{Abstract}

Islamism as one of transnational political Islam ideologies continues to spread throughout the world. Many researchers read the phenomenon of strengthening Islamism solely as part of the Islamic social movements. This article looks at it further as a threat to the social cohesiveness of contemporary society. It intends to describe the Islamism from: 1) its genealogy to ideological ideas about the unification of din (religion) and dawlah (state); 2) measuring how relevant that idea is realized in a global and national context; and 3) proposing a counter-ideology as a solution. Genealogically, Islamism ideology shows the tendency of revivalism and even fundamentalism, which tries to set Islam as a single system in society life. For contemporary Indonesia concept, the ideology is not only realistic, but is also potentially destructive to the unity, the country-nation awareness, the democracy, and Islam's mission as rahmat li al-âlamîn. Its deployment can be forestalled by revitalizing an alternative strategic discourse containing Islamic values into every dimension of life in this country. Based on the documentary review, its research findings are expected to enrich the discourse as well as an early warning system for national solidity and religious solidarity, especially in Indonesia.

Sebagai salah satu ideologi Islam-politik transnasional, Islamisme terus bergerak menyebar ke berbagai belahan dunia. Berbeda dengan sejumlah peneliti yang melihat fenomena menguatnya Islamisme sebagai bagian dari 
fenomena gerakan Islam semata, artikel ini lebih jauh melihatnya sebagai ancaman bagi kohesivitas sosial masyarakat. Artikel ini mendiskusikan dinamika Islamisme mulai dari: 1) genealogi hingga gagasan ideologisnya seputar penyatuan dîn (agama) dan dawlah (negara); 2) menakar relevansi gagasan tersebut dalam konteks global maupun nasional; dan 3) pangajuan wacana alternatif sebagai solusi. Secara genealogis, ideologi Islamisme menampilkan tendensi revivalisme dan bahkan fundamentalisme yang berupaya mengetengahkan Islam sebagai sistem tunggal kehidupan masyarakat. Untuk konteks Indonesia kontemporer, ia bukan hanya tidak realistis, tetapi juga potensial destruktif terhadap kebhinnekaan, kesadaran negara-bangsa, demokrasi, dan cita Islam sendiri sebagai rahmat li al'âlamîn. Persebarannya dapat dicegah dengan merevitalisasi suatu wacana alternatif berstrategi substantiasi nilai-nilai Islam ke dalam setiap dimensi penyelenggaran kehidupan di negeri ini. Berbekal data hasil kaji dokumen, pengkajian atasnya diharapkan menjadi pemerkaya diskursus sekaligus sebagai peringatan dini bagi soliditas kebangsaan dan solidaritas keagamaan, khususnya di Indonesia.

Keywords: conservatism; ideology; involution; islamism; state

Received: October 30, 2018; Accepted: May 21, 2019

\section{Introduction}

The commotion of ISIS (Islamic State of Iraq and Syria) have recently made many people return to discuss Islamism and its variants such as the discourse of dawlah islâmiyah (Islamic state) and khilâfah islâmiyah (Islamic khilafah). These are old discourses, both their ideas, ideological bases, religious orientations, methodological packaging, and actors or advocates and epigon groups, nothing new. However, the tendency of violence which he perceived as latent potential has now begun to manifest in various places, among others, as vulgarly held by ISIS in the Syrian and Iraqi regions and Boko Haram in Nigeria.

As a transnational Islamic-political ideology, Islamism continues to move actively spreading to various parts, including Indonesia. The global religio-political dynamics, especially related to the phenomenon of the Arab Spring, which hit some countries in the Middle East, triggered the escalation. In the country, this discourse re-blossomed and found its existential momentum in the conservative turn phenomenon midst that 
had disturbed public awareness since the adoption of the New Order regime in 1998 (van Bruinessen 2014, 24-49).

The religious conservatism symptoms lately indeed tend to continue expanding in the body of Indonesian Muslims. The phenomenon is seen among others through the occurrence of various cases of religious nuances, the rise of the presence of transnational conservative Islam networks, massive movements of radicalism elements, even religious-inspired terrorist acts, sporadic support for ISIS, widespread idea of shari'a formalization, and the reemergence of religious-political ideology named "Islamic state" or "Islamic caliphate".

The phenomenon of the conservative turn seemed to provide momentum for the revival of the ideology of Islamism which faithfully held onto the political desire to "Islamize the state" (Toriquddin 2011). Its revival is certainly worth watching out for. Not only because it saves the potential for violence in achieving its ideological goals, but also because its manifestations have the potential to disturb national diversity and unity. In terms political ideas, this ideology is a serious threat to the Republic of Indonesia (NKRI/Unitary State of the Republic of Indonesia) as well as undermining the ideals of Islam declaring as mercy to the universe (rahmat li al'âalamîn).

Regarding the Islamism phenomenon, several writings and research have reviewed it from various aspects, both in the local-national and global context. Some of the most important works include Olivier Roy (Roy 1994), Martin van Bruinessen (van Bruinessen 2012), Roel Meijer (Meijer 2009), John L. Esposito (Esposito 1992), Azyumardi Azra (Azra 1996), and Noorhaidi Hasan (Hasan 2008). All these works mention how Islamism, especially radical-oriented, in many parts of the world continues to morph into many forms despite their ideological basis and orientation practically unchanged.

Meanwhile, the study of Islamism in the local-national context has also been done quite a lot. Some are worth mentioning because they are relatively complete in revealing the configuration and dynamics of Islamism and other radical variants in Indonesia, namely the work of M. Zaki Mubarak (Mubarak 2008), Yon Machmudi (Machmudi 2008), Masdar Hilmy (Hilmy 2010), and M. Imdadun Rahmat (Rahmat 2005; 2008). They talked about the movement of Islamism as a transnational political ideology long permeated Indonesia and had become stronger since the New Order regime in 1998 by Islamists. The regime's transition momentum was used 
to reinforce the existential mode of self along with the euphoria of the Reformation and the opening of the faucet of freedom of opinion and association after 1998.

This article focuses on discussing Islamism, from genealogy to ideological ideas around the unification of religion to dawlah (state) and measuring the relevance of the idea in a global and national context. Furthermore, the discussion ends with the promotion of a counterdiscourse, an alternative ideology, against it. The submission of alternative ideological discourses is at the same time a distinction in contrast to previous works and therefore, complements discourse enrichment around the dynamics of contemporary Islamism.

\section{Ideological Genealogy}

The dynamics of the contemporary Islamic movement, historically, can be traced primarily since the seventeenth century to the twentieth century. In that century, most Islamic movements moved with almost the same spirit, namely against Western colonialism while alleviating Muslims from the confines of backwardness, poverty, ignorance, and oppression. For the XVIII and XIX century Indonesian contexts, among others, the Padri movement in Sumatra and the resistance of the tarekat in Java and Lombok were shown. While, the early twentieth century is represented, for example, by the Islamic Trade Union (SDI), Sarekat Islam (SI), Nahdlatul Ulama (NU), Islamic Unity (Persis), and Muhammadiyah (Jurdi 2013).

Ideologically, there are at least three typologies of Islamic movements in the present era, namely revivalism, reformism, and fundamentalism. These movements types emerged on a broad scale which was the fruit of Western (European) interaction with the Islamic world as well as the reaction of Muslims to Western colonial lust (Lawrence 2004, 59).

Over time, the typologies of the Islamic movement gave birth to many variants. Each of them decreases different styles of Islamic thought and ideology, even to a certain degree, paradigmatically contradict each other. Revivalism and fundamentalism, for example, among others, led to traditional conservative-style Islamic movements and puritansfundamentalists. Meanwhile, Islamic reformism which paradigmatically rests on the spirit of modernism gave birth to a variant of the Islamic movement from a reformist-modernist to a secular-modernist pattern. In the meantime, from the womb of Islamic modernism, an advanced 
character emerged, namely Islamic neo-modernism (Nashir 2013, 184-212). Beyond all the features, there are still other styles of Islamic movements, namely Islamic traditionalism which in the progressive circles raises the wings of the Islamic post-traditionalism movement (Noer 1996, 319; Rumadi 2008).

All patterns of the movement in many ways also developed in Indonesia. Especially in the context of religious and state and community relations, Islamic movements in contemporary Indonesia, ideologically, can be simplified into three categories (Hikam 2013, 224-7). First, transformative Islamic groups focusing on Islam as an integral part of Indonesianness; rejecting the dominance of Islamic ideology and making it the only alternative national life system; Islam is in a complementary position amidst the mosaic of Indonesian life. Second, the group that presents Islam as values that must dominate the constitutional and social order although not necessarily formal-institutionalized. Finally, a movement group that insists on putting Islam as the only alternative for every record or system of life, in the political, social, economic and cultural dimensions; even Islam is as a single system at the global level.

In that last category, Islamists built their existence mode. In recent studies, their famous Islamic-political ideology is called Islamism. In terms of the paradigmatic Islamic model, this ideology tends to carry an absolute pattern of Islam, an opposite diametric pattern with two other patterns, namely relatively absolute and absolutely relative (Abdullah 2006a, 82-90). This pattern focuses on the elements of culture and things that are qat'iyyatt (certain) so that their religious performance is very rigid and does not compromise the disparity of beliefs and plurality of truth.

With this pattern, Islamists try to avoid at the same time defile other thoughts or ideologies even if they emerge from religious groups, especially those emerging from the elements of other religions. In this case, they tend to apply a totalistic and formalistic understanding of religious texts. For them, the idealization and projection of the present situation and behavior of the Prophet in the post-hijrah phase of Medina are absolute. Whereas, the different contexts of the Muslims reality today in various parts of the world are not important things to consider. The attitude that then arises is zero tolerance for the treasures of local traditions while at the same time alienating all intellectualism originating from other worlds, especially the West. The effect was born an exclusive religious model and tended to worship radicalism (Syamsuddin 1993, 4-9). 
As a political ideology, Islamism rests on the principle idea that Islam is a religion and a state (al-Islâm dîn wa dawlah). It is an ideological principle that views Islam as a political system and believes that fighting for the establishment of a state or Islamic caliphate is a basic obligation of every Muslim. In recent studies, the term Islamism is increasingly used to designate the ideology of Muslim movements that make Islam a political ideology to build what is called an "Islamic State" or "Islamic Caliphate". As for the proponents, the champ called Islamists (Islamist) (Roy 1994, 35-47).

With such an ideology, Islamists not only insist on removing religious elements that are not in line with their theological and ideological beliefs but also putting the West as a common enemy. Accordingly it is not surprising, at an extreme level, that the spirit of radicalism is often legitimized as an unshakeable part of the struggle in realizing their theological-political interest (El Fadl 2005, 16-25, 220-49). That is why the term Islamism in the latest social religious studies is often used interchangeably with terms of "Islamic extremism" or "Islamic fundamentalism". Extremism and fundamentalism itself are famous nomenclatures in the literal Christian tradition, which in contemporary studies are applied simplistically to read radical movements or religions in the Islamic world (Altemeyer 2005, 378-93). In the scope of Islam, the elements of fundamentalism-extremism, in general, are born from the idea of Wahhâbî puritanism (Meijer 2009, 1-32; Armstrong 2000, ix-xvi).

Unfolding Islamism is along with the strengthening phenomenon of "religion revival" in the contemporary era (Gordis n.d.). Islamism is the most familiar marker of the Islamic revivalism phenomenon (Islamic activism) (Esposito 1992, 8). As a concept and phenomenon, "Islamic revivalism" is common to the term of activism, fundamentalism, neofundamentalism, Islamism, militancy, puritanism, reassertion, reawakening, reform, return to Islam, resurrection, revitalization, and revival. While, revivalist Muslims themselves call their movements, among others, by the name of al-ba'th al-Islâmî (Islamic renaissance), ihyâ' al-dîn (religious revival), and al-ụ̂uliyah al-Islâmiyah (Islamic fundamentalism) (Ali 2006, 27-9).

The term Islamic revivalism itself is commonly used to define various contemporary Islamic movements that originated in the Middle East and continued to expand to Muslim countries, including Indonesia, such as Hiizb al-Taḥrîr, Ikhwân al-Muslimîn, and al-Da'wah al-Salafiyah. In general, their movements display a typical movement that dynamizes religious patterns that rely on passive-apolitical spiritualism, radicalism, and 
militancy in one unit at a time (Rahmat 2008, 70-1). In the latest developments, these three Islamic organs have appeared in many ways to be the three most prominent organs of ideological Islamism in various parts of the world and immediately make Islamism a transnational ideology, crosscountry, and nation.

As a transnational political movement, the groups that defended the ideology of Islamism emerged and continued to strengthen especially after the abolition of the khilâfah institution 'Uthmânî in Turkey in 1924 (Zürcher 2010, 136-150; Fromkin 1989; Rogan 2015). As they mourned the collapse of the khilâfah institution, they continued to push for the political idea of "Islamization of the state" into the public sphere, both in terms of "Islamic state" and "Islamic caliphate". Changing the world order based on a single leadership ideology even imagined as a global one has become the cliché agenda of almost all contemporary Islamist movements, especially those with the ideology of khilafahism. It was all done to realize the wish to implement what they called "Islamic law" in all areas of power.

At the global level, recent developments show how Islamism has found the right momentum to establish itself in many Muslim-majority countries. The wave of democratization that hit some countries in the Middle East seemed to be the opening door for the rise of Islamism. Not everything went smoothly indeed, but the moment of democratization that was often termed the "Arab Spring" has made many people realize how Islamists have made it the starting point for the rise of Islamism. Over time, even the "Arab spring" (al-rabî' al-'arabî) has turned into a "spring of Islamists" (al-rabî‘ al-islâmiyyûn) (Holdo 2016, 1-16). In Tunisia, Islamists have succeeded in controlling the new government as if completing the success of their ideological counterparts in Turkey. In Egypt, Islamists briefly controlled the post-regime government of Hosni Mubarak despite being recaptured by the Military government. In Libya, they also rose despite not succeeding in creating stability. Even in parts of Syria and Iraq, radical wing Islamists have succeeded in controlling many regions and ordaining themselves as what they claim to be Islamic State of Iraq and Syria (ISIS) (Cepoi 2013, 549-60; Manhire ed. 2012).

While in the country, the phenomenon of Islamism seems to have strengthened and continues to overwhelm public space, especially since the New Order regime collapsed in 1998 (Hasan 2008, 23-51; van Bruinessen 2002). The presence of Islamists appeared and found its revival momentum as a wave of successful reforms overthrew the New Order regime, a regime 
that constantly suppressed their existence and clung to them as "extreme right". The opening of speech and association freedom became the initial momentum for the proliferation of the main organs supporting the ideology of Islamism, such as MMI (Majlis Mujahidin Indonesia), PKS (Partai Keadilan Sejahtera), and HTI (Hizb al-Tahrir Indonesia) (Hilmy 2010, 99-128).

With the ideology of Islamism, they carry out various politicalreligious agendas with militant performance and tend to be radical. Their existence is so distinctive and therefore different diametrically with predecessor socio-religious organizations, such as Nahdlatul Ulama (NU), Muhammadiyah, Nahdlatul Wathan (NW), and al-Irshad, who tend to take the path of moderation in religious thought and political praxis.

\section{Involutive Ideology}

Throughout the history of Islamism, the famous phrase, "Islâm dîn wa dawlah", has escalated some Muslim ideologies to rationalize their ideological ideals of "Islamic state" or "Islamic khilafah". By its adherents, "Islamic state" or "Islamic caliphate" is presented as a universal institution as well as a final solution to all humankind problems. The theological assumption, Islam is a universal religion that transcends regional boundaries so that the political system must also be universal and establish it as a form of absolute and universal implementation of shari'a. It is intended as an antithesis as well as a substitute for a secular political system that they consider have alienated people from the pleasure of Allah (alNabhânî 1953, 36; 1994, 236; 1996, 250). For them, only with the establishment or re-institutionalization, the lives of Muslims can be separated from all elements of infidel power, such as nationalism, secularism, and imperialism (Dekmejian 1985, 4).

Is it mandatory? In the latest Islamic studies, the so-called "Islamic state" or "Islamic khilafah" is a debatable question (ikhtilâf). Many Muslim intellectuals view that it is not obligatory to establish. One of the popular ones is 'Alî 'Abd al-Râziq, Muslim intellectual from Egypt. According to him, there is no sign, let alone a rigid concept, anything from Prophet Muhammad about the "Islamic state". Islamic religious morality and the leadership of the Prophet in Medina post-hijrah is not political-religious leadership. Strictly speaking, no historical precedent confirms the need to establish an Islamic state, both with the khilâfah and imâmah systems. There is no obligation for Muslims to establish it. The khilaffah institution is a 
political institution projected to serve a variety of political interests. It is a matter of profane, worldly, which does not adhere at all to Islam as a religion (al-Râziq 1925).

Whether to establish an Islamic state has the obligation of Islamic law or not is still debatable. However, the debate that enriched the relative discourse did not occur. The idea of an "Islamic state" or Islamic khilâfah is presented as nothing more than a mere rhetorical thought and in many ways tends to be unrealistic in an increasingly pluralistic world order and trust in a democratic system.

For most Muslims, the ideal "Islamic state" is still a prolonged dream. The seizure of Islam to the state level in many places, in fact, gave birth to another-faced oppression, namely religion. In that context, movements of practical Islamists failed to offer a model of a new prospective political society. The political victory of Islamists in several recent Muslim countries has only led to superficial achievements in the eyes of mere laws and customs, such as the Taliban in Afghanistan or ISIS in the regions of Iraq and Syria. It was proven later how the victory was not old.

However, several facts did not discourage Islamists from continuing their dreams. To this day, their dream of Islamism continues to spread. However, in recent developments, they began to experience stalemate, even facing resistance everywhere (Daftar Negara-negara yang Larang Hizbut Tahrir 2017). Existential failure begins to haunt them. Their movements are not anylonger fast, following the narrowing of their movement in various parts, especially in the Middle East such as Iraq, Syria, and Egypt. Similarly, in Indonesia, opposition to the organs of Islamism spread in various regions. The culmination was the official determination of the Government of the Republic of Indonesia towards HTI, one of the main organs of peddling Islamism, as a prohibited organization for all Indonesian regions. It was based on SK Menkumham Nr. AHU-30.AH.01.08 / 2017 concerning revocation of legal status according to Government Regulation No. 2 of 2017 (Banding Ditolak, Pembubaran HTI Tetap Sah 2018).

The bottleneck, epistemologically, is very likely to be causally related to the theoretical involution of the idea of dawlah islâmiyah (Islamic state) or khilâfah islâmiyah (Islamic khilafah) itself. It is almost no ongoing discourse enrichment from the ideologues. Overall, the ideology of Islamism tends to be involutive, stagnant, still departing and circling from a "theological" belief that simplifies the famous ideological phrase al-Islâm dîn wa dawlah. In the meantime, the dynamics of contemporary political reality tend to be 
presented and understood separately from theological ideas making it a utopia, a sense of an overly perfect social order that is too utopian to realize.

History records at least three barriers that made the movements of "Islamization of the state" experience ideological impasse (Roy 1994, 60-74). First, the stagnation of the writings as the main reference. The discourse on "Islamization of the state" tends to be frozen because it only revolves around the writings of ideologues and founders of the movement, such as Hassan al-Bannâ (Ikhwân al-Muslimîn, Egypt), Abû A'lâ al-Mawdûdî (Jamâ'at-i Islami, Pakistan and India), Sayyid Quṭb, Hassan Turâbî, Musțafâ al-Sibâ'î (Ikhwân al-Muslimîn, Syria), Shaykh Râshid al-Ghanûshî (Islamic Trend Movement, Tunis) Bâqir al-Shadr, 'Alî Shariati, Ayat Allâh Khomeini, Murtadla Muthahari, and Taqî al-Dîn al-Nabhânî (Ḥizb al-Tahrîr al-Islâmî, Palestine). After 1978, there were practically no serious writings that enriched the idea of Islamism. There are only massive reproductions of epigons without a reserve in the form of brochures, comments, quotes, and mere prayers.

Secondly, the Islamization conceptual stagnation becomes an idea that led it to a dead end. It is a fundamental problem at the reflectiontheoretical level. It also can be traced to the Islamists' assumptions about the process of institutionalizing Islam. For them, Islamic society can only be realized through politics, but its political institutions can only work if the executors have the qualifications of piety or taqwa. While the piety or taqwa, according to them, can only be extended if the community should be Islam. This postulation is like a vicious circle, spinning without end and base. Such conceptualization is held by prominent "Islamism" theorists, such Sayyid Quṭ, al-Mawdûdî to Khomeini. According to them, the enactment of Islamic shari'a in the state system or khilâfah islâmiyah will only be meaningful if the community is already Islamic and the people are already taqwa.

Third, the stagnation of action. Some of the tentative successes that they have achieved make the Islam-political activists forget about the ongoing impoverishment of discourse. What has been shown by the Islamic Republic of Iran which continues to be overwhelmed by the economic crisis, and conflicts between factions, or Afghanistan under the Taliban regime some time ago which was torn apart by clan and ethnic conflict, cannot be a representative model of what is imagined as "society Ideal Islam". There, the enforcement of Islamic law is carried out through ways of 
singleness and at the same time, closes the democratic space for the probability of differentiating interpretations of Islamic law itself.

First, they tend to present a textual-scripturalistic approach to religious understanding. This kind of character is called a symptom of logocentrism in contemporary Islamic thought (Arkoun 2002a, 170-203). With this character, their Islamic formulation is practically not visionary because the formative era of Islam in the past was seated as a single measure of truth to which all reality today must be projected. Consequently, the dynamics of contemporary Islamic thought tend to be stagnant, not revolutionary (Arkoun 2002b, 115). Such textual thought, in general, has formed an exclusive and apologetic social attitude in each of their reflections and social actions (Abdullah 2006b, 21-47). In turn, the religious patterns displayed also tend to be authoritarian rather than humanistic. It is what, directly or indirectly, fosters a variety of violent and religious nuances in various parts of the world lately, including Indonesia.

The textual way of thinking has severe consequences for the strength of their second characteristic, which tends to be all-shari'ah-minded in interpreting and responding to every reality. Islam is always called for as an institutional solution to any problem, urged like antibiotics to cure all kinds of diseases. The idea of the formalization of the shari'a which had become so widespread in the early mid-post-1998 period was the concrete manifestation of their sharîah-minded ideological desires. In that case, they have accused of secular and capitalistic democratic systems as the source of the ongoing multidimensional crisis that plagued Indonesia after the New Order.

In the meantime, they also present the third characteristic, which tends to be excessive in believing a conspiracy theory that Muslims have become victims of Western arbitrariness which continuously connects to destroy Islam, both culturally, politically, economically, and also militarily. In addition to relying on a scriptural-textual understanding of the teachings, this belief also holds the theological simplification that the West in question is Judeo-Christian civilization so that it is natural for the West always to be hostile to Muslims. All forms of resistance which they later emerged were still based on paranoia on all issues related to the relationship between Islam and the West.

Then, this tendency gave birth to the next character, namely the fourth, the tendency to be resistant to the values of pluralism by developing an anti-pluralism agenda. They view that pluralism is a Western ideological 
strategy to delegitimize the truth of Islam as the only religion blessed by Allah. Based on textual interpretations of Islamic teachings, they believe that Christians and Jews are "damned people" who always try to convert Muslims. Consequently, they tend to distinguish seriously between friends and opponents. Gaps with other groups are the result; people outside the group are considered different entities to treat differently. Of course, this causes them always to find it challenging to establish productive coexistence with other groups amid plurality.

These four religious characteristics, in turn, have strengthened a religious model relying on exclusivism, which in turn broadens the spirit of radicalism and intolerance (Hussein 2005, 29-31). The strong exclusivism tendency indeed leads to the problem of organizing "living together", both internally (with fellow Muslim groups) and externally (with non-Muslims). Various exclusive agendas that prioritize the interests of Islamism, such as the formalization of the shari'a and excessive suspicion of the others have sparked massive threats among minorities (Umam 2016, 365-88).

Intolerant attitudes are a logical consequence of a religious model that lives exclusivism. Therefore, the potential and actual exclusive diversity have become a serious threat to the creation of social cohesiveness in a pluralistic and multicultural society, such as in Indonesia. The performance of the extremists and militants has had an impact on the difficulty of religious adherents to dialogue with each other and co-existence in diversity. Logically, because exclusive religiosity only views its justified beliefs, while others are wrong. To a certain extent, the religious model leads people into the trap of radicalism or extremism in religion, even in the state (Hussein 2005, 30-1). At this point, Islamism is not only a problem in creating social cohesion in a pluralistic and multicultural Indonesian society but also threatens the integrity of the NKRI.

This conclusion is not excessive. At least there are three serious implications of the movement of Islamism that have the potential to destroy the life of the nation, state, and also religion in many countries, including Indonesia (al Qurtuby 2003). First, the politics of "Islamization of the state" criticized by Islamists has proven to escalate the potential for disintegration among groups of people in the country concerned. In some countries, Islamism has fueled and increased sectarian tensions between various groups in society, for example, in Pakistan (Rashid 1995). The strategy of Islamization through the mastery of state apparatus can be 
counterproductive so that the goal of creating a civilized society becomes increasingly far from the fire.

The second implication is that the political movement of Islamism will trigger new tensions as a further impact of the discriminatory character necessarily in the religion-based constitution (Islam) itself. Ethnic and language disparities are indeed not fundamental in the determination of a constitution based on Islamic law (Tabandeh 1970, 17-20), and therefore, their discriminatory character does not emerge. However, on non-Muslim minority issues, as well as gender issues, differences in provisions that have discriminatory tendencies are very prominent in them, for example in terms of criminal matters, family matters, and the matter of witnessing. It is possible that massive, structured, and systematic social persecution will occur if such shari'a is applied as public law. On the contrary, the situation is better, fair, and humane (for Muslims and non-Muslims; for women and men), it is possible to create precisely if a society applies secular public law (al-Na'im 1990).

Furthermore, the third implication, the politics of Islamism, will also immediately open the door for the rise of authoritarianism and totalitarianism of power in the name of Islam. The constitution designed must necessitate the authoritarian and totalitarian interests. It is logical considering that Islamism always presupposes a constitution based on ilâhiyah legitimacy. The legitimacy not limited by any human person or any institution inevitably makes the constitution impossible to restrict and/or correct the power of the ruler (the khaliffah).

\section{Value Substantiation}

If this is the case, then how realistic is the idea of an "Islamic state" or "Islamic khilaffah"? Is it relevant, for example, be applied in a heterogeneous religious socio-cultural situation in Indonesia? For the sake of weighing contemporary reality while remembering its theory, it must be said that the idea is irrelevant, unrealistic, and therefore its utopian presence.

The utopia of institutionalizing khilâfah or dawlah Islam is mainly related to its own theological and political desires to unite the world in a single leadership. It is impossible to remember the heterogeneity of contemporary world civilization, including in matters of religion. In terms of supposing just theological legitimacy, the practical "Islamic khilâfah" or "Islamic state" would be a problem for non-Muslims. The cost is too 
expensive, especially when forced by violence. With this idea, Islamism is risking for the main ideals of Islam itself as a blessing for all (rahmat li al(âlamîn).

It has not counted the vulnerability of authoritarianism and totalitarianism in the name of religion, which of course is opposed to the trend of democratization in various parts of the world. That is logical, because modern democracy as adopted by the nation-state relies on the claim that "people's voices are God's voice" (vox populi vox dei). It is clearly incompatible with the khilafah system which relies on the opposite claim, namely vox dei vox populi (God's voice is the voice of the people) (Azra 2007).

For mere theological leadership, the institutionalization of khilafah might be possible, although it remains limited to become a unifying symbol. It also is not without problems; for instance, the uniformity of thought or appreciation of the Islamic ummah is divided into various schools of thought and flow. Shî‘ ah certainly refused and immediately proposed the imâmah system. Sunnî also differs in their internal views. At that point, humility is needed for the heterogeneous facts of the religious community. The ontological claim that Islam is single is ahistorical. Islamic civilization, as is known, is overcrowded by many variants, even down to the question 'aqîdah (theology).

The diversity of interpretations of Islamic law certainly has consequences for the diversity of application forms. When the shari'a is "institutionalized as a state" in the form of "Islamic state" and "Islamic khilâfah", people will undoubtedly ask whose the shari'a model is, what, and how they want to be used as a benchmark. Each group inevitably submits its school of thought or interests "shar' 1 ". That is the fundamental epistemological problem faced by every endeavor "Islamization of the state". It directly or indirectly, in many ways, has led to all the movements that reject Islamism to reap cliche failures. On the theoretical level alone, the whole idea of Islamism certainly will not be able to avoid the contradictions, controversies, and ambiguities. That is why, to reduce it, Islamism always imposes a single truth claim while carrying out the agenda of uniformity. Various forms of violence, as seen in many regions in the Middle East today, by Islamist groups are evidence that forcing Islamic claims and uniformity on them is indeed an integral part of the "struggle" breath. 
This counterproductive evidence is enough as an excuse to question the great narrative of Islamism. Moreover, the dark history of Islamic politics teaches how the phenomenon of the growth of Islam with politics/state often precisely traps the first entity. Islam, which is intended to regulate political life, often experience all-out exploitation for political purposes. Instead of countries that serve the interests of Islamic teachings, it is Islam that is often forced to serve the lust of the political power of the elites. Against this factual fact, it is not excessive when Abdelwahab elAffendi, a Sudanese philosopher once said curtly, "Most of Islamic history is the history of bastards who claim to rule in the name of God" (el-Affendi 1994, 55).

When "Islamization of the state" in the style of Islamism turns out to be unrealistic, utopian, and even counterproductive for the Islamic ideal itself as a blessing for the universe, Muslims need to consider other "Islamization" models and strategies. One of them is the substitution of Islamic values, an attempt to enculturate values Islam into the whole system of implementing state life. Substantiation of values means not institutionalizing Islam formally into the body of the state (read: "Islamic state" or "Islamic khilâfah"), but supporting the entire system of state administration with substantive values of Islam. They are justice (al-'adâlah), equality of degrees (al-musâwah), freedom (al-hurriyah), democracy (al-shûrâ), kindness (al-khayr), amr ma'rûf nahiy munkar, and the like.

To the extent that these values have been embodied into the system of state administration, it is no longer important whatever the pattern, form, model, and structure of power. It does not matter the formal form and model of the country, whether it is a kingdom, republic, "Islamic state" or "secular state" or any model country. This strategy does not care about symbols, packaging, outer skin, containers, but instead concentrates on how the state-run system cares these values. In the condition of society that is not at all homogeneous, especially in religion such as Indonesia, the strategy of deformalization, depoliticization, and symbolization of religion (Islam) in such a way is more realistic, productive, effective. Therefore, it is more likely to be accepted and carried out by all components of the nation.

The strategy of "Islamization" in such a way is an opposing discourse (counter-discourse). In the context of the latest Indonesian-ness, the choice is more strategic and productive. As a discourse of competition, this strategy basically means carrying out efforts to revitalize Islamic values of rahmat li al- 
'âlamin. Further, it also manifests the commitment to maintain the integrity of the Republic of Indonesia, Pancasila, the 1945 Constitution, and the diversity from the undermining of ideological Islamism that wants to "close the screen" Indonesia as a country.

At a certain point, this strategy benefits the interests of Islamic

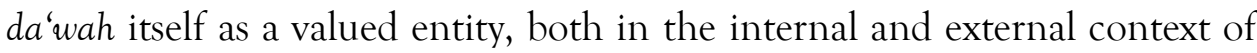
the Ummah. Schuon states that "Islam spread throughout the world like lightning thanks to its substance and stalled because of its form" (Schuon 1993, 25). It is enough to be a handle for Muslims to get involved in the dynamics of state, nation, and religious life in this country.

\section{Conclusion}

With the ideology of Islamism, Islamists play a pattern of a tendency towards revivalism and even fundamentalism, which ideologically insists on designing Islam as a single system of people's lives. So far, the dynamics of their movement seems to be a distinctive marker of the growing religious sentiments in public spaces. They have helped to disperse various conflicts and violence to a certain extent and threaten democracy, human rights, national unity, and national culture.

The strengthening of the Islamism phenomenon in the country lately is not only a sign of the Islamic movement revival but also a threat to the social cohesiveness of the community. The strong sense of conservatism led to the involution of discourse in itself has made the ideology of Islamists appear as potential and actual threats. It refers to the threats especially towards diversity, awareness of the nation-state, democracy, and also the ideals of Islam as a blessing for the universe (rahmat li al-âlamîn). Unfortunately, the state has so far tended not to respond swiftly to the potential plots of ideology that Islamists brings; likewise, the people, tend to be ignorant. The negative response that later appeared seemed late because it began to emerge when the analyst of Islamism had already spread to educational institutions, even to the state apparatus.

Considering all the destructive threats, the spread of the ideology of Islamism must be dammed. Certainly not through violence. In the name of democracy and human rights, the range of the discourse of Islamism can be resisted, rivaled, with the revitalization of opposing discourses with the strategy of substantiating Islamic values into every dimension of the delivery of life in this country. Amid religious and national factual heterogeneity, this strategy is more realistic, relevant, and potentially productive for the 
future of the NKRI. At least, the revitalization of the strategy is expected to be a discourse enrichment as well as a kind of early warning system for strengthening national solidarity and religious solidarity in this country.

\section{References}

Abdullah, M. Amin. 2006a. "Dilema Antara Konservasi Nilai Tradisi Keislaman dan Penyebaran Etos Perdamaian: Pimpinan Agama Memerlukan Kemampuan Dua Bahasa." In Fenomena Konflik Sosial di Indonesia: Dari Aceh Sampai Papua, eds. Koeswinarno and Dudung Abdurrahman. Yogyakarta: Lemlit UIN Sunan Kalijaga Yogyakarta: 21-47.

Abdullah, M. Amin. 2006b. Islamic Studies di Perguruan Tinggi Pendekatan Integratif-Interkonektif. Yogyakarta: Pustaka Pelajar.

Ali, Jan Ashik. 2006. "Islamic Revivalism: A Study of the Tablighi Jamaat in Sydney." Dissertation. University of New South Wales, Sydney.

Al Qurtuby, Sumanto. 2003. "Dilema Politisasi Islam." In http://www. suarapembaruan.com/News/2003/12/14 (August 27, 2018).

Altemeyer, Bob. 2005. "Fundamentalism and Authoritarianism." In Handbook of the Psychology of Religion and Spirituality, eds. Raymond F. Paloutzian and Crystal L. Park. New York: The Guilford Press: 37893.

Al-Na'im, Abdullahi Ahmed. 1990. Toward an Islamic Reformation: Civil Liberties, Human Rights, and International Law. New York: Syracuse University Press.

Anwar, Syafi'i. 2008. "Memetakan Teologi Politik dan Anatomi Gerakan Salafi Militan di Indonesia.” In M. Zaki Mubarak, Genealogi Islam Radikal di Indonesia: Gerakan, Pemikiran, dan Prospek Demokrasi. Jakarta: LP3ES: xvii-xx.

Arkoun, Mohammed. 2002a. The Unthought in Contemporary Islamic Thought. London: Saqi Books - The Institute of Ismaili Studies.

Arkoun, Mohammed. 2002b. Al-Fikr al-Ușûlî wa Istihâhlat al-Ta'ṣîl: Nahwa Târîkh Akhar li al-Fikr al-Islâmî. London: Dâr al-Sâqî. 
Armstrong, Karen. 2000. The Battle for God: Fundamentalism in Judaism, Christianity, and Islam. London: HarperCollins.

Azra, Azyumardi. 1996. Pergolakan Politik Islam: Dari Fundamentalisme, Modernisme hingga Post-Modernisme. Jakarta: Paramadina.

Azra, Azyumardi. 2007. "Relevansi Khilafah di Indonesia." Kompas. August 18.

van Bruinessen, Martin. 2014. Conservative Turn: Islam Indonesia dalam Ancaman Fundamentalisme. Bandung: Al-Mizan.

van Bruinessen. 2012. "Genealogies of Islamic Radicalism in post-Suharto Indonesia." South East Asia Research 10(2): 117-54.

DOI: https://doi.org/10.5367/000000002101297035

"Banding Ditolak, Pembubaran HTI Tetap Sah" 2018. https://m.detik.com/news/berita/d-4229634/banding-ditolakpembubaran-hti-tetap-sah (September 30, 2018).

Cepoi, Ecaterina. 2013. "The Rise of Islamism in Contemporary Syria: From Muslim Brotherhood to Salafi-Jihadi Rebels." Studia Politica: Romanian Political Science Review 13(3): 549-60.

"Daftar Negara-negara yang Larang Hizbut Tahrir." 2017. https://m.detik.com/news/berita/d-3496023/daftar-negara-negarayang-larang-hizbut-tahrir/ (October 10, 2018).

Dekmejian, R. Hrair. 1985. Islam in Revolution: Fundamentalism in the Arab World. New York: Syracuse University Press.

El-Affendi, Abdelwahab. 1994. Masyarakat Tak Bernegara: Kritik Teori Politik Islam. Trans. Amiruddin Ar-Rani. Yogyakarta: LKíS.

El Fadl, Khaled M. Abou. 2005. The Great Theft: Wrestling Islam from the Extremists. New York: Harper SanFrancisco.

Esposito, John L. 1992. The Islamic Threat: Myth or Reality?. New York: Oxford University Press.

Fromkin, David. 1989. A Peace to End All Peace: The Fall of the Ottoman Empire and the Creation of the Modern Middle East. New York: Henry Holt and Company. 
Gordis, Robert. n.d. "The Revival of Religion and the Decay of Ethics." In http://www.religion-online.org/showarticle.asp?title=1438 (October 2, 2018).

Hasan, Noorhaidi. 2008. "Reformasi, Religious Diversity, and Islamic Radicalism after Suharto.” Journal of Indonesian Social Sciences and Humanities 1: 23-51.

Hikam, Muhamad AS. 2013. Gus Dur Ku, Gus Dur Anda, Gus Dur Kita: Kenangan, Wawancara Imajiner, dan Guyon Gusdurian. Bandung: Yrama Widya.

Hilmy, Masdar. 2010. Islamism and Democracy in Indonesia: Piety and Pragmatism. Singapore: Institute of Southeast Asian Studies.

Holdo, Markus. 2016. "Post-Islamism and Fields of Contention after the Arab Spring: Feminism, Salafism, and the Revolutionary Youth." Third World Quarterly 38(8): 1800-15.

DOI: https://doi.org/10.1080/01436597.2016.1233492

Husein, Fatimah. 2005. Muslim-Christian Relations in the New Order Indonesia: The Exclusivist and Inclusivist Muslims' Perspectives. Bandung: Mizan.

Jurdi, Syarifuddin. 2013. "Gerakan Sosial Islam: Kemunculan, Eskalasi, Pembentukan Blok Politik dan Tipologi Artikulasi Gerakan.” Jurnal Politik Profetik 1(1): 1-24.

DOI: https://doi.org/10.24252/jpp.v1i1.1615

Lawrence, Bruce B. 2004. Islam Tidak Tunggal: Melepaskan Islam dari Kekerasan. Trans. Harimukti Bagoes Oka. Jakarta: Serambi.

Machmudi, Yon. 2008. Islamising Indonesia: The Rise of Jamaah Tarbiyah and the Prosperous Justice Party (PKS). Canberra: ANU Press.

Manhire, Toby, ed. 2012. The Arab Spring: Rebellion, Revolution, and a New World Order. London: Guardian Books.

Meijer, Roel. 2009. "Introduction." In Global Salafism: Islam's New Religious Movement, ed. Roel Meijer. London: Hurst \& Company: 1-32.

Mubarak, M. Zaki. 2008. Genealogi Islam Radikal di Indonesia: Gerakan, Pemikiran, dan Prospek Demokrasi. Jakarta: LP3ES. 
al-Nabhânî, Taqî al-Dîn. 1953. al-Shakhsiyyah al-Islâmiyyah, Vol. 3. Beirut: Dâr al-Ummah.

al-Nabhânî, Taqî al-Dîn. 1994. al-Dawlah al-Islâmiyah. Beirut: Dâr al-Islâm.

al-Nabhânî, Taqî al-Dîn. 1996. Nizâm al-Hukm fî al-Islâm. Beirut: Dâr alUmmah.

Nashir, Haedar. 2013. Islam Syariat: Reproduksi Salafiyah Ideologis di Indoensia. Bandung: Mizan.

Noer, Deliar. 1996. Gerakan Modern Islam di Indonesia 1900-1942. Jakarta: LP3ES.

Rahmat, M. Imdadun. 2005. Arus Baru Islam Radikal: Transmisi Revivalisme Islam Timur Tengah ke Indonesia. Jakarta: Penerbit Erlangga.

Rahmat, M. Imdadun. 2008. Ideologi Politik PKS: Dari Masjid Kampus ke Gedung Parlemen. Yogyakarta: LKíS Yogyakarta.

Rashid, Ahmed. 1995. "The Great Divide: Shias and Sunnis Battle It Out in Pakistan.” Far Eastern Economic Review 9.

al-Râziq, 'Alî 'Abd. 1925. al-Islâm wa Uṣûl al-Hukm: Bahth fî al-Khilâfah wa alHukûma fî al-Islâm. Cairo: Maṭa'at Misr.

Rogan, Eugene. 2015. The Fall of Ottoman: The Great War in the Middle East. New York: Basic Books.

Roy, Olivier. 1994. The Failure of Political Islam. Massachusetts: Harvard University Press.

Rumadi. 2008. Post-tradisionalisme Islam: Wacana Intelektualilsme dalam Komunitas NU. Cirebon: Fahmina Institute.

Schuon, Frithjof. 1993. Islam dan Filsafat Perenial. Trans. Rahmani Astuti. Bandung: Mizan.

Syamsuddin, M. Din. 1993. "Usaha Pencarian Konsep Negara dalam Sejarah Pemikiran Politik Islam.” Ulumul Qur'an 2: 4-9.

Tabandeh, Sultanhussein. 1970. A Muslim Commentary on the Universal Declaration of Human Rights. London: F.T. Goulding and Co. 
Toriquddin, Moh. 2011. "Mapping Fiqh Siyasi: Islamis Versus Sekularis dan Khilafah Versus nation State." Ulul Albab: Jurnal Studi Islam 12(1): 50-66.

DOI: http://dx.doi.org/10.18860/ua.v0i0.2396

Umam, Fawaizul. 2016. "Memaknai Keragaman: The Others dalam Konstruksi Sosial Para Elit Kelompok Keagamaan di Kota Mataram." Jurnal Theologia 27(2): 365-88.

DOI: http://dx.doi.org/10.21580/teo.2016.27.2.931

Zürcher, Erik J. 2010. The Young Turk Legacy and Nation Building: From the Ottoman Empire to Atatürk's Turkey. New York: I.B. Tauris. 